\title{
Correction: Population type influences the rate of ageing
}

\section{Andrew DJ. Overall ${ }^{1} \cdot$ Richard GA. Faragher $^{1}$}

Published online: 7 May 2019

(c) The Author(s) 2019. This article is published with open access

\section{Correction to: Heredity;}

https://doi.org/10.1038/s41437-019-0187-1;

published online 08 February 2019

This article was originally published under standard License to Publish, but has now been made available under a CC BY 4.0 license. The PDF and HTML versions of the paper have been modified accordingly.

\begin{abstract}
Open Access This article is licensed under a Creative Commons Attribution 4.0 International License, which permits use, sharing, adaptation, distribution and reproduction in any medium or format, as long as you give appropriate credit to the original author(s) and the source, provide a link to the Creative Commons license, and indicate if changes were made. The images or other third party material in this article are included in the article's Creative Commons license, unless indicated otherwise in a credit line to the material. If material is not included in the article's Creative Commons license and your intended use is not permitted by statutory regulation or exceeds the permitted use, you will need to obtain permission directly from the copyright holder. To view a copy of this license, visit http://creativecommons. org/licenses/by/4.0/.
\end{abstract}

Andrew DJ. Overall

a.d.j.overall@brighton.ac.uk

1 School of Pharmacy and Biomolecular Sciences, Huxley Building, University of Brighton, Brighton, East Sussex BN2 4GJ, UK 